\title{
Artesunate-tinospora combination treatment decreases nuclear factor kappa-B and intercellular adhesion molecule-1 expression in mouse malarial models
}

\author{
Nur Izzati*, Loeki Enggar Fitri**, and Mochammad Dalhar***
}

\begin{abstract}
* Master of Biomedical Science Program,

Study Program for Specialist in Neurology,

Faculty of Medicine,

Brawijaya University/

RSUD dr.Saiful Anwar

Malang

**Department of Parasitology,

Faculty of Medicine,

\section{BACKGROUND}

Cerebral malaria is a severe form of malaria caused by brain ischemia. Artesunate, an artemisinin derivative, is the standard WHO therapy for severe malaria. Tinospora crispa (brotowali) is a traditional plant with antiinflammatory, antioxidant and antiparasitic properties. The aim of this study was to determine the effect of combinations of artesunate and T. crispa extract on nuclear factor kappa-B (NFKB) and intercellular adhesion molecule-1 (ICAM-1) expression in the brain of mouse malaria models.
\end{abstract}

Brawijaya University, Malang

***Department of Neurology,

Faculty of Medicine,

Brawijaya University/

RSUD dr.Saiful Anwar, Malang

\section{Correspondence:}

dr. Nur Izzati

Faculty of Medicine, Brawijaya

University/RSUD dr.Saiful Anwar

Malang

Jl. Jaksa Agung Suprapto No.2,

Malang

Phone: +62341321297

Mobile: +62811 3093891

Email: dr.Nizzah@gmail.com

Univ Med 2016;35:222-8

DOI: 10.18051/UnivMed.2016.v35.222-228 pISSN: 1907-3062 / eISSN: 2407-2230

This open access article is distributed under a Creative Commons Attribution-Non

Commercial-Share Alike 4.0 International License

\section{METHODS}

This was an experimental post-test only control group study using C57BL/ $6 \mathrm{~J}$ mice infected with Plasmodium berghei, divided into 7 groups: negative control, positive control, group receiving artesunate $32 \mathrm{mg} / \mathrm{kgBW}$, group receiving tinospora extract $3.5 \mathrm{mg} / \mathrm{kgBW}$, and three groups receiving combinations of artesunate $32 \mathrm{mg} / \mathrm{kgBW}$ and tinospora extract $2.5 \mathrm{mg} /$ $\mathrm{kgBW}, 3 \mathrm{mg} / \mathrm{kgBW}$ and $3.5 \mathrm{mg} / \mathrm{BW}$, respectively. The expression of $\mathrm{NFKB}$ and ICAM-1 was measured by immunohistochemistry. One-way ANOVA was used to analyze the data.

\section{RESULTS}

NFKB and ICAM-1 expression increased significantly in the positive controls compared to all other groups $(\mathrm{p}=0.000)$. NFKB expression was significantly lower in the groups receiving artesunate and tinospora at 3 $\mathrm{mg} / \mathrm{kgBW}$ and $3.5 \mathrm{mg} / \mathrm{kgBW}$, as compared with the artesunate only group $(\mathrm{p}=0.003 ; \mathrm{p}=0.005)$ and the tinospora extract only group $(\mathrm{p}=0.001$; $\mathrm{p}=0.003)$. NFKB expression in all combination treatment groups was similar to that in the negative controls ( $p>0.05$ ), whereas ICAM-1 expression did not differ between single and combination treatment groups ( $>0.05)$.

\section{CONCLUSION}

The combination of artesunate and T. crispa extract is better in decreasing NFKB and ICAM-1 expression in the brain of mouse malaria models.

Keywords: Artesunate, tinospora , ICAM-1, malaria, NFאB, mouse 


\section{INTRODUCTION}

Malaria is an important cause of death, especially in tropical countries. In 2013, there were 198 million cases of malaria in the world, resulting in 584,000 deaths. ${ }^{(1)}$ The pathophysiology of cerebral malaria is not clearly understood. Erythrocytes infected with $P$. falciparum and undergoing rupture release glycosyl phosphatidyl inositol (GPI) molecules from the parasite, thereby inducing tumor necrosis factor $\alpha$ (TNF- $\alpha)$. The latter activates the transcription of nuclear factor kappa-B (NFKB) which triggers the expression of various mediators of inflammation (including intercellular adhesion molecule-1, ICAM-1) and the innate immune response. ${ }^{(2)}$

The World Health Organization malaria guidelines since 2006 have recommend the use of artemisinin-based combination theraphy (ACT) to prevent antimalarial drug resistance. ${ }^{(1,3)}$ Artesunate is an artemisinin derivative with endoperoxide structure that rapidly eradicates the asexual erythrocytic stages of $P$. vivax and $P$. falciparum. The drug is 10-100 times more potent in eradicating malarial parasites than other antimalarial drugs. ${ }^{(4)}$

Brotowali (Tinospora crispa (L) Miers) of the family Menispermaceae is a traditional medicinal plant that is widely used as antimalarial, antipyretic, antidiabetic, antiinflammatory, and analgesic agent. T. crispa contains a bitter substance, i.e. tinocrisposide, and several alkaloids such as aporphine, berberine and palmatine. ${ }^{(5)}$ In a study of 10 Malaysian medicinal plants, using methanol extracts at concentratiosn of $0.03 \mu \mathrm{g} / \mathrm{ml}, T$. crispa stem extract showed the highest in vitro antiplasmodial activity to $P$. falciparum at $90 \%$ growth inhibition. ${ }^{(6)}$ Berberine and palmatine significantly inhibit the activation of NFKB and decrease the expression of ICAM1 and transforming growth factor-beta 1 (TGF$\beta 1)$ in mesangial cells of rats with diabetic nephropathy, while berberine also inhibits inducible nitric oxide synthase (iNOS) expression. $^{(7,8)}$
One study showed the protective effects of Tinospora crispa stem extract on renal damage and hemolysis in Plasmodium berghei infection. ${ }^{(9)}$ There is no information on studies about the effect of $T$. crispa and artesunate administration on the expression of NFKB and ICAM-1 in the brain of mouse malaria models.

The purpose of this study was to evaluate the effect of a combination of artesunate and tinospora stem extract on the expression of NFKB and ICAM-1 in the brain of mouse malaria models.

\section{METHODS}

\section{Design of the study}

This study used an experimental post-test only control group design and was conducted in the Parasitology and Biomedical Laboratory, Faculty of Medicine, Brawijaya University, Malang, from January 2015 until February 2016.

\section{Experimental animals}

The test animals used were mice of the C57BL/6J strain, which were obtained from the Eijkman Institute, Jakarta, where randomization was performed. The inclusion criteria were: females, weighing 20-25 grams, aged 12-16 weeks. The sample size was determined using the formula $\mathrm{p}(\mathrm{n}-1) \geq 15$, where $\mathrm{p}=$ number of intervention groups and $n=$ number of replications. ${ }^{(10)}$

All subjects were allocated by simple randomization into 7 treatment groups: group I (negative controls), group II (positive controls), group III (artesunate $32 \mathrm{mg} / \mathrm{kgBW}$ ), group IV (tinospora extract $3.5 \mathrm{mg} / \mathrm{kgBW}$ ), group $\mathrm{V}$ (combination treatment $\mathrm{A}=$ artesunate $32 \mathrm{mg} /$ $\mathrm{kgBW}$ and tinospora extract $2.5 \mathrm{mg} / \mathrm{kgBW}$ ), group VI (combination treatment $\mathrm{B}=$ artesunate 32 $\mathrm{mg} / \mathrm{kg}$ and tinospora extract $3 \mathrm{mg} / \mathrm{gBW}$ ), and group VII (combination treatment $\mathrm{C}=$ artesunate $32 \mathrm{mg} / \mathrm{kgBW}$ and tinospora extract $3.5 \mathrm{mg} /$ $\mathrm{kgBW}$ ). Administration of artesunate $32 \mathrm{mg} /$ $\mathrm{kgBW}$ was by single daily intraperitoneal injection on days 4,5 , and 6 post infection, ${ }^{(11)}$ while 
tinospora extract was administered once daily by gavage on days 4,5 , and 6 post infection. Dissection was performed on day 7 after inoculation.

\section{Parasites and infection}

The mice were inoculated intraperitoneally with $1 \times 10^{7}$ P. berghei-infected erythrocytes.

\section{Preparation and administration of $T$. crispa stem extract}

Extraction was performed at the Chemistry Research Center of the Indonesian Scientific Institute (LIPI), Bandung. The extract was then subjected to phytochemical analysis and thin-layer chromatography (TLC). Administration of tinospora extract at $2.5 \mathrm{mg} / \mathrm{kgBW}, 3 \mathrm{mg} / \mathrm{kgBW}$, and $3.5 \mathrm{mg} / \mathrm{kgBW}$ was performed by dissolving the extract in $0.2 \mathrm{ml}$ of distilled water and administering the solution orally by gavage, starting on day 4 and continuing for 3 days.

\section{Immunohistochemistry of NFKB and ICAM-1}

As an initial step, antigen retrieval with citrate buffer was performed, then immunohistochemical staining as follows: the slides were dripped with $3 \% \mathrm{H}_{2} \mathrm{O}_{2}$ in methanol, incubated for 15 minutes, and washed 3 times with PBS for 2 minutes each. Then blocking of nonspecific protein was done. Onto the slides were dripped NFKB primary antibody (NFKB in a 1:300 dilution in phosphate buffered solution (PBS) and $2 \%$ bovine serum albumin (BSA), and ICAM-1 primary antibody (ICAM-1 in a 1:50 diution in PBS-BSA). The slides were then incubated with secondary antibody and afterwards with streptavidin-horseradish peroxidase (SAHRP) for 20 minutes. Then diaminobenzidine (DAB) and DAB buffer were dripped in a ratio of 1:50. Subsequently Mayer's hematoxylin and tap water were dripped in a ratio of $1: 10$, then the slides were rinsed with tap water and dried.

\section{Evaluation}

Expression of NFKB and ICAM-1 was observed under the microscope at $400 \mathrm{x}$ magnification in 10 fields of view. All nucleated cells expressing NFKB showed brown-colored nuclei and cytoplasms, ${ }^{(12)}$ whereas cells expressing ICAM-1, particularly vascular endothelial cells, showed brown-colored cytoplasms. ${ }^{(13)}$

\section{Statistical analysis}

The statistical analysis was performed using oneway ANOVA followed by the Tukey test to find the differing parameters, with level of significance set at $\mathrm{p}<0.05$.

\section{Ethical clearance}

The present study was approved by the Ethics Commission, Faculty of Medicine, Brawijaya University, Malang.

\section{RESULTS}

From the phytochemical and TLC tests it the respective total phenolic and flavonoid contents were found to be $43.34 \pm 1.92 \%$ and $74.26 \pm$ $1.32 \%$ of dry weight.

The obtained values for NFKB and ICAM-

1 expression are shown in Table 1. Mean expression of NFKB and ICAM-1 was significantly different between the seven treatment groups $(p=0.000 ; p=0.000)$. The lowest mean expression of NFKB and ICAM-1 was found in the artesunate-tinospora combination groups. The immunohistochemical test results on NFKB and ICAM-1 expression are shown in Figures 1 and 2 , respectively.

The Tukey test showed a significant difference in NFKB expression between the negative control group versus the positive control group $(\mathrm{p}=0.000)$, the artesunate group $(\mathrm{p}=0.001)$, and the tinosporaextract group $(\mathrm{p}=0.001)$, but no significant difference between the negative control group and each of the combination treatment groups $(\mathrm{p}=0.142 ; \mathrm{p}=1,000 ; \mathrm{p}=0.986)$. Positive control group was significantly different from all other groups $(\mathrm{p}<0.05)$. The artesunate group was not significantly different from the tinosporaextract group $(\mathrm{p}=1.000)$ and the combination treatment A groups $(\mathrm{p}=0.192)$. There was 
Table 1. Mean NFKB and ICAM-1 expression by treatment group

\begin{tabular}{lcccccccc}
\hline & \multicolumn{7}{c}{ Treatment grou } & \multirow{2}{*}{} \\
\cline { 2 - 8 } & I(n=3) & II(n=3) & III (nF3) & IV(n=3) & V(n=3) & V (n=3) & VII (nF3) & p \\
\hline NFKB & $15.33 \pm 2.08$ & $51.00 \pm 2.65$ & $25.00 \pm 1.00$ & $25.67 \pm 1.53$ & $20.33 \pm 3.06$ & $16.00 \pm 2.65$ & $16.67 \pm 1.53$ & 0.000 \\
ICAM-1 & $11.33 \pm 2.08$ & $44.33 \pm 4.04$ & $23.00 \pm 3.61$ & $20.00 \pm 2.00$ & $19.67 \pm 4.16$ & $18.00 \pm 2.52$ & $16.33 \pm 2.52$ & 0.000 \\
\hline
\end{tabular}

I: negative control; II: positive control; III: artesunate $32 \mathrm{mg} / \mathrm{kg} \mathrm{BW}$; IV: tinospora extract $3.5 \mathrm{mg} / \mathrm{kg}$; V: artesunate $32 \mathrm{mg} /$ $\mathrm{kg} \mathrm{BW}+$ tinospora extract $2.5 \mathrm{mg} / \mathrm{kg} \mathrm{BW}$; VI: artesunate $32 \mathrm{mg} / \mathrm{kg} \mathrm{BW}+$ tinospora extract $3 \mathrm{mg} / \mathrm{kg} \mathrm{BW}$; VII: artesunate $32 \mathrm{mg} / \mathrm{kg} \mathrm{BW}+$ tinospora extract $3.5 \mathrm{mg} / \mathrm{kg} \mathrm{BW}$

significant difference in NFKB expression between the artesunate grup and the combination treatment B grup $(\mathrm{p}=0.003)$, the combination treatment $\mathrm{C}$ groups $(\mathrm{p}=0.005)$. In addition, there was significant difference between tinospora extract group and the combination treatment $\mathrm{B}(\mathrm{p}=0.001)$, the combination treatment $\mathrm{C}$ groups $(\mathrm{p}=0.003)$. (data not shown).

The Tukey test showed a significant difference between the negative control group versus the positive control group ( $\mathrm{p}=0.000$ ), the artesunate group $(\mathrm{p}=0.005)$, and the tinospora extract group $(\mathrm{p}=0.045)$, but no significant difference between the negative control group and each of the combination treatment groups ( $p=0.057 ; p=0.176 ; p=0.453)$. Group II or positive control group was significantly different from all other groups $(\mathrm{p}<0.05)$. ICAM-1 expression in the artesunate group was not significantly different from that in each of the combination treatment groups $(\mathrm{p}=0.824 ; \mathrm{p}=0.453$; $\mathrm{p}=0.762$ ). In addition, there was no significant difference in ICAM-1 expression between the tinospora extract group and each of the combination treatment groups $(\mathrm{p}=1.00 ; \mathrm{p}=0.981$; $\mathrm{p}=0.757$ ) (data not shown).
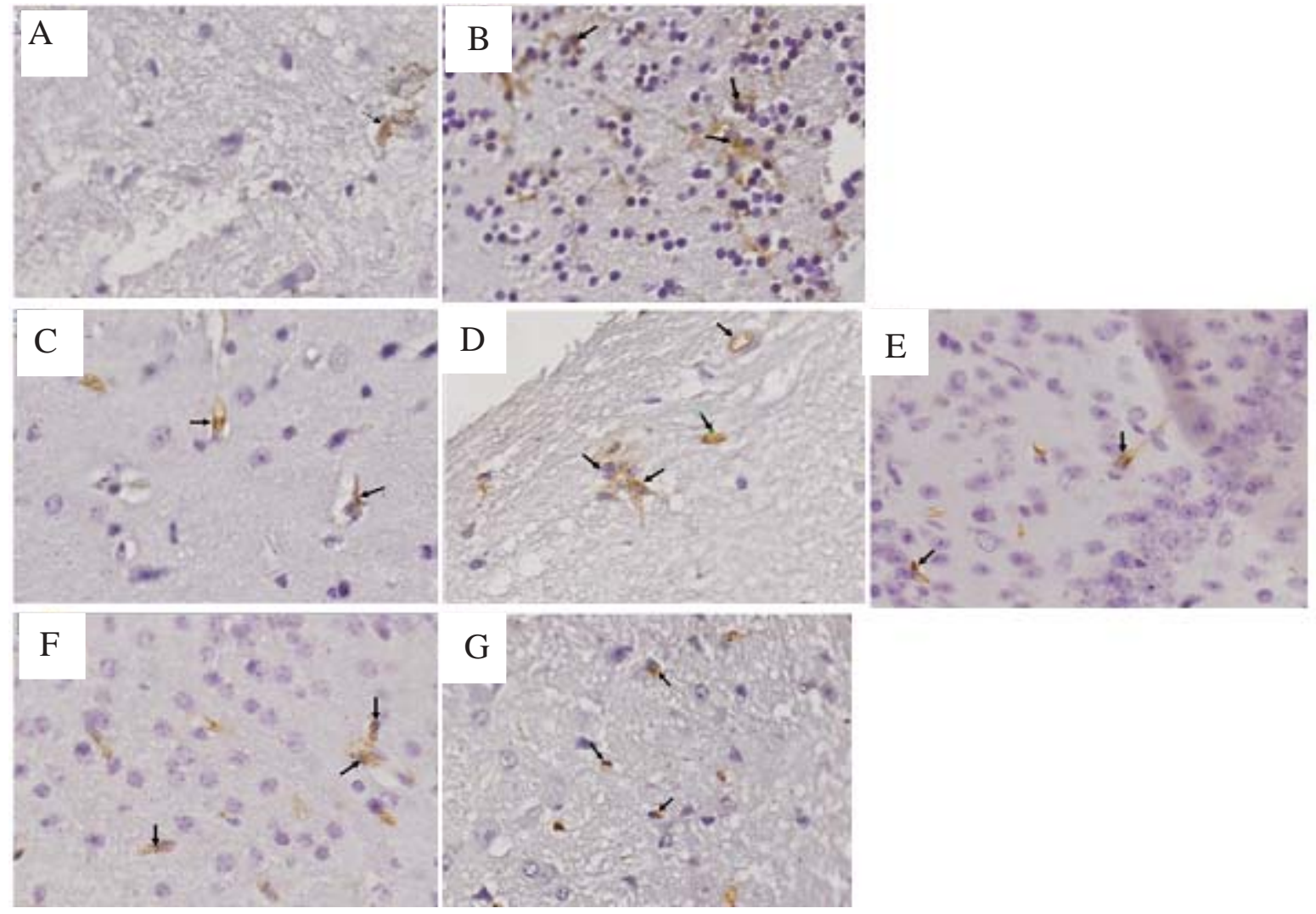

Figure 1. NFKB expression by immunohistochemistry (400x)

(A) Negative control, (B) Positive control, (C) Artesunate, (D) Tinospora extract, (E) Combination treatment A, (F) Combination treatment B, (G) Combination treatment C. Arrows indicate NFkB expressing cells 

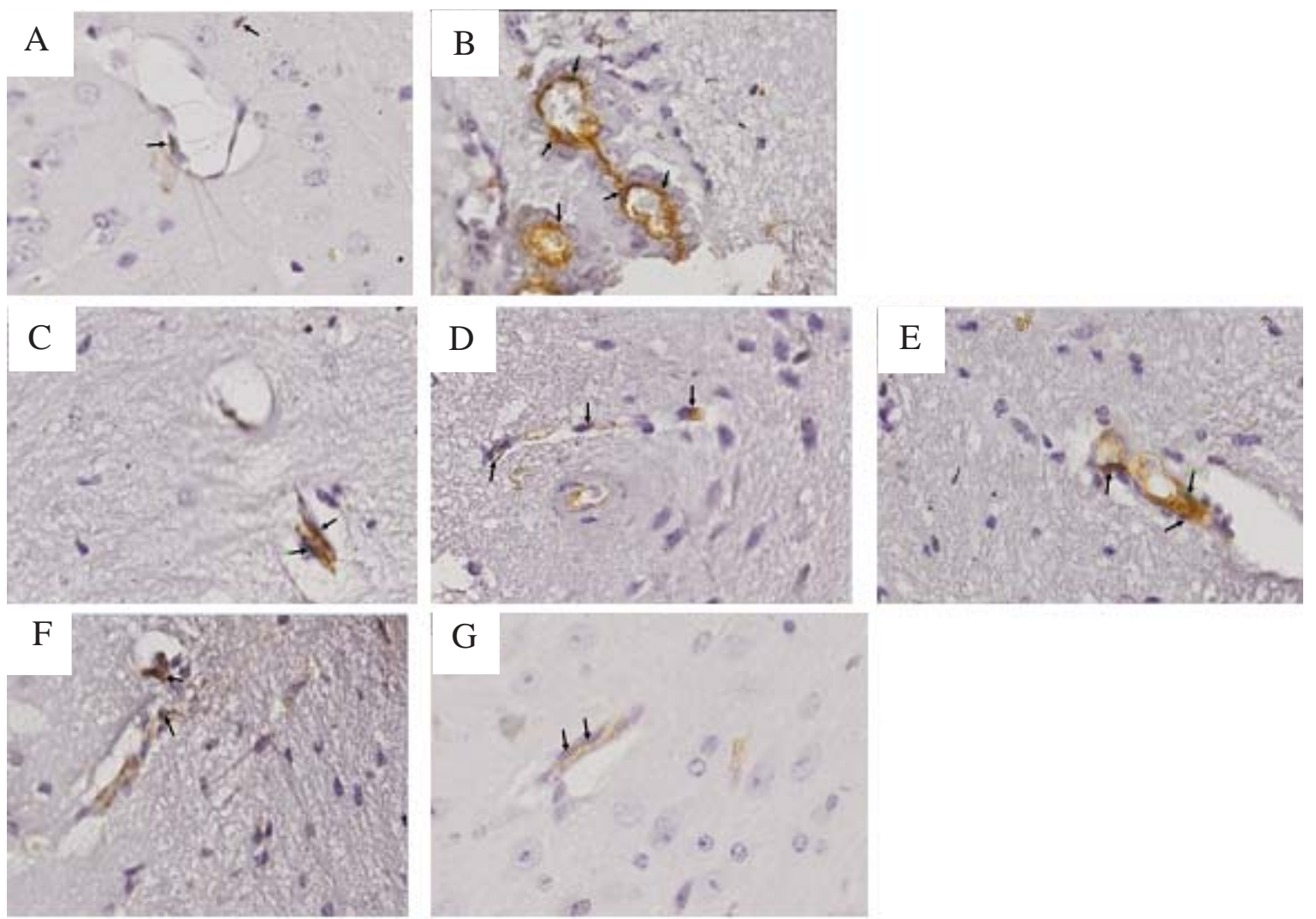

Figure 2. ICAM-1 expression by immunohistochemistry (400x)

(A) Negative control, (B) Positive control, (C) Artesunate, (D) Tinospora extract, (E) Combination treatment A, (F) Combination treatment B, (G) Combination treatment C. Arrows indicate ICAM-1-expressing cells

\section{DISCUSSION}

Cerebral malaria is a form of severe malaria that is caused by brain ischemia and may result in death. The severity of cerebral malaria is assumed to be caused by dysregulation of homeostasis between pro- and anti-inflammatory conditions. ${ }^{(14-16)}$

Infection with Plasmodium affects the erythrocytes, thus leading to parasitemia. The surface of the membrane of parasitized erytrocytes is covered with knobs called PfEMP-1, which are surface antigens that bind to ICAM- 1 in the vascular endothelium. The parasitized erytrocytes rupture and release toxic molecules from the parasite, i.e. glycosyl phosphatidyl inositol (GPI) molecules, which induce mononuclear cells to produce pro-inflammatory cytokines, such as tumor necrosis factor alpha (TNF- $\alpha$ ), interleukin1 alpha (IL- $1 \alpha$ ), IL-6, IL-10, IL-1 $\beta$, IFN- $\gamma$ and others through activation of the transcription factor NFKB. These pro-inflammatory cytokines then induce the activation of $\mathrm{NFKB},{ }^{(2)}$ thereby increasing NFKB proteins, which in the brain are predominantly expressed by microglia and astrocytes. ${ }^{(12)}$ In the present study it was found that NFKB expression in the positive control group was exceedingly high and differed significantly from that in the treatment groups.

In this study, upon administration of tinospora extract decreases in both NFKB and ICAM-1 expression were found. This is due to the fact that tinospora extract has antiinflammatory, antioxidant, and antiparasitic activities, which are mainly caused by phenolics, flavonoids, and alkaloids in all parts of the plant, such as leaves, fruits, seeds, roots, and bark. ${ }^{(5,17)}$ In this study the sample of tinospora stem extract tested on TLC showed a content of total phenolics of $43.34 \%$ and total flavonoids of $74.26 \%$, which are high for tinospora and represent its antiinflammatory and antioxidant properties. The antioxidant test conducted by Ibrahim et al. ${ }^{(13)}$ showed that a methanolic extract of T. crispa had 
the highest antioxidant activity dependent on total flavonoid and phenolic content, and an activity against free radicals of 2,2 diphenyl 2 picryl hydrazyl hydrate (DPPH).

The excellent anti-inflammatory activity of berberine that has been observed in vitro and in vivo showed decreases in pro-inflammatory cytokines in the acute phase. The NFKB pathway plays an important role in the control of inflammation and is one of the main targets of the anti-inflammatory activity of berberine. In the

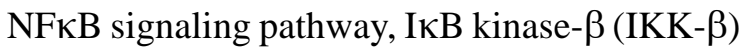
may be activated by stimulation by inflammatory cytokines such as TNF- $\alpha$. Activation of IKK- $\beta$ requires phosphorylation of serine (ser-181). Administration of berberine substantially decreases ser-181 phosphorylation and IKK- $\beta$ activation. ${ }^{(18,19)}$ The anti-inflammatory and antioxidative activity of berberine is also mediated through the AMPK and Nrf2/HO pathways. ${ }^{(20)}$ In vitro, berberine and palmatine may inhibit $\mathrm{NO}$ production and NFKB activation in macrophages, that is stimulated by LPS or TNF- $\alpha .{ }^{(21)}$

Artesunate is a first-line antimalarial drug which has been demonstrated to be effective as compared with other artemisinin derivatives. However, its use in monotherapy may cause recrudescence, therefore it should be used in combination with other drugs. ${ }^{(1)}$ Tukey's post hoc test showed that combination therapy caused a greater and significantly different decrease in NFKB expression as compared with the groups receiving monotherapy with artesunate or tinospora extract.

According to previous studies, the pharmacokinetic properties of berberine are as follows: half-life $\left(\mathrm{T}_{1 / 2}\right) 945.8$ minutes, time to reach maximum drug concentration $\left(\mathrm{T}_{\max }\right) 15.0$ minutes, peak plasma concentration $\left(\mathrm{C}_{\max }\right) 20.0$ $\mathrm{ng} / \mathrm{mL}$, area under plasma concentration from time point 0 until a given time point $\mathrm{t}\left(\mathrm{AUC}_{0 \rightarrow \mathrm{t}}\right) 4954.3$ minutes-ng/mL, distribution volume $5124.3 \mathrm{~L} / \mathrm{kg}$ and total body clearance (CL) $198.6 \mathrm{~L} / \mathrm{hour} / \mathrm{kg} .{ }^{(22)}$

In a previous study, the in vivo antimalarial effect of T. crispa extract at a dose of $80 \mathrm{mg} / \mathrm{kg} /$ day showed inhibitory activity on the growth of P.yoelii. ${ }^{(23)}$ In another study, a methanolic extract of T. crispa stems had in vitro anti-plasmodial activity against $P$. falciparum strain $3 \mathrm{D} 7$ with $\mathrm{IC}_{50}$ values between $0.27 \mathrm{mg} / \mathrm{ml}$ and $0.29 \mathrm{mg} / \mathrm{ml}$, while the effective inhibitory dose was $2.0 \mathrm{mg} / \mathrm{ml}$, at which dose the parasitemia decreased to $7.62 \%$ and $5.85 \%$ after 48 and 72 hours, respectively, resulting in a mean reduction of parasitemia degree by $47.12 \%$ and $56.83 \%$, respectively. ${ }^{(24)}$

A limitation of the present study was the fact that the mice were sacrificed on day 7 only, therefore precluding comparison with a longer treatment period to find the effect of length of drug and herbal administration.

Further studies should be conducted to determine whether or not combination therapy of artesunate and tinospora extract also has inhibitory effects on other pro-inflammatory cytokines, apart from ICAM-1, in which the production depends on NFKB activation. In addition, there is a need to conduct studies on the benefits and safety of tinospora extract for human malaria through clinical trials and their stages or phases.

\section{CONCLUSION}

Combination therapy with artesunate and tinospora extract results in a higher reduction in NFKB and ICAM-1 expression in the brain of mouse malaria models as compared with artesunate therapy.

\section{CONFLICT OF INTEREST}

None declared.

\section{ACKNOWLEDGEMENT}

The authors wish to express their gratitude to the Head of the Parasitology and Biomedical Laboratory, Brawijaya University, Malang, for the use of facilities in the completion of this study.

\section{REFERENCES}

1. World Health Organization. World malaria report. Geneva: World Health Organization; 2015. 
2. Punsawad C, Yaowapa M, Urai C,et al. Nuclear factor kappa B modulates apoptosis in the brain endothelial cells and intravascular leukocytes of fatal cerebral malaria. Malaria J 2013;12:1-12.

3. Patel JP, Gami B, Patel K. Evaluation of in vitro schizontocidal properties of acetone extract of some Indian medicinal plants. Adv Biol Res 2010;4:253-8.

4. Brown GD. The biosynthesis of artemisinin (qinghaosu) and the phytochemistry of Artemisia annua L. (qinghao). Molecules 2010;15:760398.

5. Ahmad W, Jantan I, Bukhari SNA. Tinospora crispa (L.) Hook.f. \& Thomson: a review of its ethnobotanical, phytochemical, and pharmacological aspects. Front Pharmacol 2016; 7:59. doi: 10.3389/fphar.2016.00059.

6. Omar AW, Patimah I. Plant-derived antimalarial agents: from crude extracts to isolated bioactive compounds. Malaysian J Med Health Sci 2011;7: 87-98.

7. Jiang Q, Liu P, Wu X, et al. Berberine attenuates lipopolysaccharide-induced extracelluar matrix accumulation and inflammation in rat mesangial cells: involvement of NFKB signaling pathway. Mol Cell Endocrinol 2011;331:34-40.

8. Kamarazaman IS, Amom ZH, Ali RM, et al. Protective effect of Tinospora crispa extract on $\mathrm{H} 2 \mathrm{O} 2$-induced oxidative stress and TNF- $\alpha$ induced inflammation on human umbilical vein endothelial cells (HUVECs). J Medicinal Plants Res 2012;6:3013-21. DOI: 10.5897/JMPR11. 1510.

9. Nutham N, Sakulmettatham S, Klongthalay S, et al. Protective effects of Tinospora crispa stem extract on renal damage and hemolysis during Plasmodium berghei infection in mice. J Pathogens; 2015. Article ID 738608, 5 pages. http://dx.doi.org/10.1155/2015/738608.

10. Solimun. Metode penelitian kuantitatif. Bandung: Alfabeta;2001.

11. Clemmer L, Martin YC, Zanini GM, et al. Artemether and artesunate show the highest efficacies in rescuing mice with late-stage cerebral malaria and rapidly decrease leukocyte accumulation in the brain. Antimicrob Agents Chemother 2011;55:1383-90.

12. Uffort DG, Grimm AE, Ellerhorst JA. NFкB mediates mitogen-activated protein kinase pathway-dependent iNOS expression in human melanoma. J Invest Dermatol 2009;129:148-54.

13. Ibrahim MJ, Wan Nor WMZ, Narimah AHH, et al. Anti-proliperative and antioxidant effects of Tinospora crispa (Batawali). Biomed Res 2011; 22:57-62.
14. Sarfo BY, Wilson NO, Bond VC, et al. Plasmodium berghei ANKA infection increases Foxp3, IL-10 and IL-2 in CXCL-10 deficient C57BL/6 mice. Malaria J 2011;28;1-69.

15. Alphonsus CS, Rodseth RN. The endothelial glycocalyx: a review of the vascular barrier. Anaesth 2014;69:777-84.

16. Cabrales P, Yuri CM, Peng KO, et al. Cerebral tissue oxygenation impairment during experimental cerebral malaria. Virulence 2013;15;4:686-97. doi: 10.4161/viru.26348.

17. Zhang L, Ravipati AS, Koyyalamudi SR, et al. Antioxidant and antiinflammatory activities of selected medicinal plants containing phenolic and flavonoid compounds. J Agr Food Chem 2011;59:12361-7. doi: 10.1021/jf203146e.

18. Moghaddam HK, Baluchnejadmojarad T, Roghani M, et al. Berberine ameliorate oxidative stress and astrogliosis in the hippocampus of STZ-induced diabetic rats. Mol Neurobiol 2013; 49:820-6.

19. Wang Y. Attenuation of berberine on lipopolysaccharide-induced inflammatory and apoptosis responses in $\beta$-cells via TLR4independent JNK/NF- $\mathrm{BB}$ pathway. Pharm Biol 2013;52:532-8.

20. Mo C, Wang L, Zhang J, et al. The crosstalk betweenNrf2 and AMPK signal pathways is important for the anti-inflammatory effect of berberine in LPS-stimulated macrophages and endotoxin-shocked mice. Antioxid Redox Signal 2013;20:574-88. doi: 10.1089/ars.2012.5116.

21. Liu L, Huq S, Xu W. Targetting cyclooxygenase and nitric oxide pathway crosstalk: a new signal transduction pathway for developing more effective anti inflammatory drugs. Curr Signal Transduct Ther 2009;4:66-75.

22. Gong Z, Chen Y, Zhang R, et al. Pharmacokinetics of two alkaloids after oral administration of Rhizoma Coptidis extract in normal rats and irritable bowel syndrome rats. Evid Based Complement Alternat Med 2014, Article ID 845048, 8 pages. http://dx.doi.org/ $10.1155 / 2014 / 845048$.

23. Rungruang T, Boonmars T. In vivo antiparasitic activity of the Thai traditional medicine plant Tinospora crispa against Plasmodium yoelii. Southeast Asian J Trop Med Public Health 2009; 40:898-900.

24. Ihwan, Rifa'i M, Fitri LE. Antiplasmodial test of Tinospora crispa stem extract against Plasmodium falciparum 3D7 strain in vitro [Uji anti plasmodium ekstrak batang Tinospora crispa terhadap Plasmodium falciparum galur 3D7 secara in vitro]. Jurnal Kedokteran Brawijaya 2014;28:91-6. 